\title{
AKTIVITAS ANTIMIKROBA EKSTRAK ETIL ASETAT JAMUR LAUT YANG DIISOLASI DARI ORGANISME LAUT SPONS Phylospongioa lamellosa YANG DIAMBIL DARI PERAIRAN DESA TUMBAK, KECAMATAN PUSOMAEN, KABUPATEN MINAHASA TENGGARA TERHADAP MIKROBA Staphylococcus aureus, Escherichia coli, dan Candida albicans
}

\author{
Priscilia Irene Tumiwa ${ }^{1)}$, Adithya Yudistira ${ }^{1)}$, Defny S. Wewengkang ${ }^{1)}$ \\ 1)Program Studi Farmasi FMIPA UNSRAT Manado, 95115
}

\begin{abstract}
Sponges are multi-cell marine invertebrates whose tissue and organ functions are very simple which live in coral reef ecosystems. Sponges are known to produce bioactive compounds because of their symbiotic relationships with microorganisms so that they have the potential to be developed in the field of medicine including as an antimicrobial. This study aims to determine whether the fungus associated with Phyllospongia lamellose sponge taken from the waters of, Southeast Minahasa Regency has antimicrobial activity. This research includes sampling, isolation and fungal inoculation, fermentation, extraction with acetone and then fractionated with ethyl acetate solvent,dried until it gets crude extracts and is carried out as well as antimicrobial testing against Staphylococcus aureus, Escherichia coli, and Candida albicans. Antimicrobial activity was obtained from inhibitory zones formed around the paper disk against the test microbes. From the results of the study concluded that the fungus associated with the Phyllospongia lamellose sponge has antimicrobial activity against the bacteria Staphylococcus aureus, Escherichia coli, and Candida albicans.
\end{abstract}

Keywords: Phyllospongia lamellose sponge, Antimicrobial, Stapylococcus aureu, Escherichia coli, Candida albicans.

\begin{abstract}
ABSTRAK
Spons merupakan invertebrata laut multi sel yang fungsi jaringan dan organnya sangat sederhana yang hidup pada ekosistem terumbu karang. Spons diketahui menghasilkan senyawa bioaktif karena adanya hubungan simbiotik dengan mikro organisme sehingga berpotensi untuk dikembangkan dalam bidang pengobatan diantaranya sebagi antimikroba. Penelitian ini bertujuan untuk mengetahui apakah jamur yang berasosiasi dengan spons Phyllospongia lamellose yang diambil dari perairan Desa Tumbak, Kecamatan Posumaen, Kabupaten Minahasa Tenggara memiliki aktivitas antimikroba. Penelitian ini meliputi kegiatan pengambilan sampel spons Phyllospongia lamellose, isolasi dan inokulasi jamur yang berasosiasi dengan spons, fermentasi, ektraksi dengan aseton kemudian difraksinasi dengan pelarut etil asetat, dikeringkan hingga mendapat ekstrak kasar dan dilakukan serta pengujian antimikroba terhadap bakteri Staphylococcus aureus, Escherichia coli, dan jamur Candida albicans. Aktivitas antimikroba didapatkan dari zona hambat yang terbentuk disekitaran cakram kertas terhadap mikroba uji. Dari hasil penelitian disimpulkan bahwa jamur yang berasosiasi dengan spons Phyllospongia lamellose memiliki aktivitas antimikroba terhadap bakteri Staphylococcus aureus, Escherichia coli, dan jamur Candida albicans.
\end{abstract}

Kata Kunci : Spons Phyllospongia lamellose, Antimikroba, Stapylococcus aureu, Escherichia coli, Candida albicans. 


\section{PENDAHULUAN}

Antimikroba merupakan senyawa alami, semi sintetik yang menghalangi atau menghambat organisme bersifat komensal atau patogenik. Dengan sedikit atau tidak ada kerugian pada inangnya. Antimikroba diklasifikasikan berdasarkan spektrumnya, mekanisme aksi, strain penghasil, cara biosintesis, maupun struktur biokimianya. Menurut Nikham dan Taty (2012), mekanisme kerja antimikroba adalah menghambat biosintesis dinding sel, meningkatkan permeabilitas membran sel, dan mengganggu sintesis protein sel, sehingga menghambat pertumbuhan atau menyebabkan kematian sel bakteri.

Spons laut memiliki potensi bioaktif yang sangat besar (Bara, 2007). Kemampuan spons dalam menghasilkan senyawa bioaktif karena adanya hubungan simbiotik dengan mikro organisme. Jamur dan bakteri yang bersimbiosis dengan spons memiliki potensi yang besar dan diduga kuat berperan menghasilkan senyawasenyawa bioaktif yang selama ini diisolasi dari spons (Lee et al, 2001). Reddy et al. (2011), jumlah metabolit sekunder yang diisolasi dari jamur laut yang bersimbiosis dengan alga, sponge, avertebrata lainnya dan sedimen sebagai antibakteri, antijamur dan sitotoksik ratarata $75 \%$ memiliki aktivitas biologis. Samuel et al. (2011), tahun 2002-2004, dari jamur laut telah ditemukan 272 produk alami baru, hal ini membuktikan bahwa jamur laut memiliki potensi farmakologis.

Jamur laut diketahui memiliki kontribusi yang penting. Banyak jenis jamur laut yang telah diisolasi dan diketahui menghasilkan sejumlah senyawa antimikroba, seperti alkaloid, makrolid, terpenoid, derivat peptida, dan struktur lainnya yang kini menjadi pilihan baru untuk melawan penyakit infeksius. Jamur laut memiliki kelimpahannya yang tinggi, namun yang sudah diteliti masih kurang dari 5\%. Jamur mampu menghasilkan senyawa yang berpotensi diaplikasikan dalam dunia kesehatan dan telah dibuktikan memiliki banyak sumber metabolit sekunder aktif yang unik secara struktur (Bugni, 2004). Jamur tersebut dapat bersifat obligat, yaitu tumbuh bersporulasi di laut, atau bersifat fakultatif, yaitu berasal dari lingkungan air tawar atau darat yang mampu tumbuh dan juga bersporulasi di lingkungan laut (Kohlmeyer 1979). Sekarang ini perkembangan resistensi terhadap antimikroba dan munculnya patogen multiresisten telah membangkitkan kepedulian kalangan medis di dunia. Hal ini telah menjadi permasalahan yang sangat penting untuk diselesaikan. Bakteri multidrug resistant adalah bakteri yang telah resisten terhadap dua atau lebih golongan antibiotik. Infeksi yang disebabkan oleh bakteri resisten dikaitkan dengan angka perawatan rumah sakit yang lebih tinggi, masa perawatan rumah sakit yang lebih lama, serta tingkat kesakitan dan kematian yang lebih tinggi (Sastroasmoro, 2005).

\section{METODOLOGI PENELITIAN Bentuk Penelitian}

Penelitian ini dilaksanakan menggunakan metode eksperimental laboratorium yang akan menguji aktivitas antimikroba mikroorganisme yang diisolasi dari spons

\section{Waktu dan Tempat Penelitian}

Penelitian ini telah dilaksanakan pada bulan Maret sampai bulan September 2019 di Laboratorium Farmasi Lanjut Fakultas Matematika dan Imu Pengetahuan Alam Universitas Sam Ratulangi.

\section{Alat}

Alat yang digunakan dalam penelitian ini yaitu masker, sarung tangan, gunting, scuba diving,kantong plastik, kamera bawah laut, wadah kaca, pisau, Erlenmeyer (pyrex), corong, rotary evaporator, timbangan digital, gelas ukur (pyrex), gelas kimia (pyrex), cawan petri, corong pisah (pyrex), autoklaf, pinset, spatula, pembakar spritus, magnetic stirrer, pipet tetes, mikro tub, batang pengaduk, 
Laminar air flow,rak tabung reaksi, tabung reaksi, lemari pendingin, inkubator, cakram (paper disc), mikropipet, vial, jangka sorong, jarum ose, jas lab.

\section{Bahan}

Bahan-bahan yang digunakan yaitu spons, bakteri uji Staphylococcus aureus ATCC 25923, Escherichia coli ATCC 25922, Jamur Uji Candida albicans ATCC 1231, etanol, aquadest, etil asetat, aseton, Potato Dextros Agar, Nutrient Agar, Glukosa, Polypeptone, MgSO4.7H2O, Yeast Extract, KH2PO4, Sukrosa, Starch, Malt Extract, Ebios, label, spidol permanen, tissue, aluminium foil, kertas saring, kapas.

\section{Pengambilan Sampel}

Sampel spons diambil di Desa Tumbak, Kecamatan Posumaen, Kabupaten Minahasa Tenggara. menggunakan alat bantu (Scuba Diving). Sampel difoto dengan kamera bawah laut dan diambil lalu dimasukkan ke dalam ziper bag dan disimpan dalam cooling box berisi es batu untuk dibawa ke Laboratorium Lanjutan Program Studi Farmasi Fakultas Matematika dan Imu Pengetahuan Alam Universitas Sam Ratulangi.

\section{Isolasi dan Purifikasi Jamur yang Berasosiasi dengan Spons}

Isolasi jamur dilakukan dengan cara sampel dibersihkan dengan aquades kemudian dipotong kecil-kecil menggunakan gunting dan pinset dan dimasukkan ke dalam media PDA yang telah disiapkan. Sampel ditanam di atas media PDA dengan tiga titik pusat yang berbentuk segitiga. Cawan petri yang berisi sampel ditutup dan direkatkan menggunakan parafilm, kemudian diinkubasi pada suhu ruangan selama $7 \times 24$ jam. Setelah didapatkan isolat jamur, dilakukan pemurnian dengan cara isolat jamur diinokulasikan ke media PDA yang baru, kemudian diinkubasi pada suhu ruangan selama 14x24 jam. Selanjutnya diidentifikasi morfologi secara makroskopik untuk menghasilkan isolat jamur murni.

\section{Kultur Cair}

Kultur cair dilakukan dengan cara biakan jamur murni yang telah diperoleh diinokulasikan ke dalam labu erlenmeyer yang berisi (2 gram glukosa, 0,5 gram polypeptone, 0,05 gram $\mathrm{MgSO} 4.7 \mathrm{H} 2 \mathrm{O}, 0,2$ gram yeast extract, 0,1 gram $\mathrm{KH} 2 \mathrm{PO} 4$, dan 0,1 gram agar ditambahkan $100 \mathrm{ml}$ aquades). Labu tersebut kemudian diaduk menggunakan alat shaker pada suhu $270 \mathrm{C}$ dengan kecepatan $120 \mathrm{rpm}$ selama $3 \times 24$ jam untuk memperoleh bibit kultur. Setelah didapatkan bibit kultur, kemudian dipindahkan sebanyak $3 \mathrm{ml}$ ke media produksi yang berisi (4,5 gram sukrosa, 4,5 gram starch, 1,5 gram ekstrak malt, 0,45 Ebios, 0,75 gram KH2PO4, dan 0,075 $\mathrm{MgSO} 4.7 \mathrm{H} 2 \mathrm{O}$ dalam $150 \mathrm{ml}$ aquades). Labu tersebut kemudian diaduk menggunakan alat shaker pada suhu $270 \mathrm{C}$ dengan kecepatan $120 \mathrm{rpm}$ selama 7x24 jam.

\section{Ekstraksi dan Fraksinasi}

Pada akhir hari ketujuh setelah proses fermentasi, dilakukan ekstraksi pada campuran miselium jamur dan broth dengan menggunakan $200 \mathrm{~mL}$ aseton. Dilakukan Ekstraksi pada campuran miselium jamur dan broth dengan menggunakan aseton. Ekstraksi dilakukan dengan menggunakan shaker pada suhu ruangan dengan kecepatan $150 \mathrm{rpm}$ selama 5 menit. Selanjutnya dipisahkan antara fase air dan aseton menggunakan corong pisah dan kertas saring. Setelah didaptkan filtrat dari hasil penyaringan kemudian diuapkan dengan rotary evaporator. Setelah didapatkan ekstrak kental dari hasil evaporasi, dimasukkan ke dalam corong pisah dan ditambahkan pelarut etil asetat sebanyak $200 \mathrm{~mL}$ setelah itu dikocok dalam corong pisah sampai homogen. Dibiarkan sampai terbentuk dua lapisan. Masingmasing lapisan ditampung pada wadah 
yang berbeda. Lapisan $\mathrm{H}_{2} \mathrm{O}$ kemudian difraksinasi lagi menggunakan pelarut etil asetat sebanyak $200 \mathrm{ml}$. Hal ini dilakukan sebanyak tiga kali. Selanjutnya fraksi etil asetat dikumpulkan kemudian pelarut diuapkan menggunakan rotary evaporator sampai diperoleh ekstrak kasar etil asetat yang akan digunakan untuk uji aktivitas antimikroba.

\section{Pengujian aktivitas antimikroba}

Metode yang digunakan dalam penelitian ini yaitu metode difusi agar (disc diffusion Kirby and Bauer). Aktivitas penghambatannya diuji terhadap Staphylococcus aureus ATCC 25923 (bakteri Gram positif), Eschrichia coli ATCC 25922 (bakteri Gram negatif) dan Candida albicans ATCC 1231 (jamur), yang digunakan sebagai mikroorganisme uji. Pada pengujian aktivitas antimikroba ini, cakram (paper disc) yang digunakan berukuran $6 \mathrm{~mm}$. Suspensi mikroba kemudian diinokulasikan ke dalam media dan dihomogenkan. Kemudian media yang telah diinokulasi mikroba dituangkan ke dalam cawan petri dan tunggu sampai media memadat. Masing-masing cawan petri diberi label dan nomor sampel yang sesuai. Sampel yang telah ditentukkan konsentrasinya $(250 \mu \mathrm{g} / 50 \mu \mathrm{l})$ ditotolkan pada masing-masing cakram dengan menggunakan mikropipet. Letakkan kertas cakram yang telah ditotolkan sampel uji dengan pinset kedalam cawan petri lalu diinkubasi selama 1 x 24 jam (Ortez, 2005).

\section{Pengamatan dan Pengukuran Zona Hambat}

Pengamatan dilakukan setelah $1 \times 24$ jam masa inkubasi. Zona bening merupakan petunjuk kepekaan mikroba terhadap bahan antimikroba yang digunakan sebagai bahan uji yang dinyatakan dengan lebar diameter zona hambat (Vandepite, 2005). Diameter zona hambat diukur kemudian dikategorikan kekuatan daya antimikrobanya berdasarkan penggolongan Davis dan Stout (1971).

\section{Pengolahan dan Analisis Data}

Teknik pengolahan data dilakukan dengan model penyajian dalam bentuk tabel dan gambar. Aktivitas antibakteri diukur dengan menggunakan jangka sorong skla millimeter berdasarkan zona hambat yang terbentuk,kemudian di rata-ratakan dari tiga kali pengujian.

\section{HASIL DAN PEMBAHASAN Determinasi Spons}

Determinasi spons dilakukan dilakukan di Laboratorium Lanjut Program Studi Farmasi Universitas Sam Ratulangi Manado. Tujuan dilakukannya determinasi untuk mengetahui sampel yang diambil ialah tepat sehingga terhindar dari kesalahan penggunaan sampel dalam penelitian. Hasil dari identifikasi sampel menunjukkan bahwa jenis spons yang hendak diteliti adalah spons Phyllospongia lamellosa

\section{Isolasi dan Fermentasi}

Sampel yang telah disiapkan kemudian dibersihkan dengan aquades untuk menghilangkan kotoran dan mikroorganisme epifit, sehingga koloni yang tumbuh pada media isolasi merupakan koloni simbion (Arnold et al., 2000). Selanjutnya penanaman jamur yang berasosiasi dengan spons Phyllospongia lamellose dilakukan dengan cara dipotong berukuran kecil kemudian ditanam di atas media PDA. Dalam penelitian ini, isolat jamur dikultivasi sebanyak dua kali dengan periode yang berbeda. Kultivasi pertama dilakukan selama $3 \times 24$ jam untuk memperoleh bibit kultur. Setelah hari ketiga dari kultivasi pertama, selanjutnya kultivasi kedua dilakukan selama 14x24 jam untuk memproduksi senyawa dari bibit kultur. Kultivasi dilakukan pada media cair dengan metode shaker pada suhu $27^{\circ} \mathrm{C}$ dengan kecepatan $150 \mathrm{rpm}$, dan dipantau 
setiap hari untuk memeriksa pertumbuhan mikroorganisme koloni dari spons Phyllospongia lamellose. Diamati hasil isolat jamur yang pertumbuhan koloninya paling dominan kemudian diinokulasikan ke media PDA baru untuk dilakukan pemurnian. Pemurnian isolat jamur bertujuan untuk memisahkan hasil inokulasi yang terdiri dari banyak koloni yang berlainan jenis sehingga didapat koloni murni pada setiap cawan petri (Hadioetomo, 1990). Setelah dilakukan pemurnian selama 14 x 24 jam didapatkan isolat jamur murni yaitu isolat yang mengandung satu bentuk morfologi koloni yang sama. Isolat jamur murni kemudian difermentasi dengan tujuan untuk memperbanyak mikroorganisme. Fermentasi isolat jamur murni dilakukan dengan fermentasi cair. Media fermentasi terdiri dari glukosa, polypeptone, $\mathrm{MgSO}_{4} .7 \mathrm{H}_{2} \mathrm{O}$, yeast extract, $\mathrm{KH}_{2} \mathrm{PO}_{4}$, pati, extract Malt, ebios dimana semuanya merupakan sumber nutrisi untuk pertumbuhan jamur. Hal ini diperkuat dengan pernyataan oleh Hadietomo (1990), nutrien dalam media pembenihan harus mengandung seluruh elemen yang penting untuk sintesis biologik organisme baru. Proses fermentasi dilakukan pada media cair dengan metode shaker pada suhu $27^{\circ} \mathrm{C}$ dengan kecepatan $150 \mathrm{rpm}$, hal ini bertujuan agar media pembenihan dan media produksi tetap homogen dan dapat digunakan oleh jamur secara optimal sebagai bahan untuk proses metabolismenya sehingga senyawa antimikroba dapat dihasilkan dengan optimal.

\section{Ekstraksi dan Fraksinasi}

Ekstraksi isolat jamur dari spons Phyllospongia lamellose dimaksudkan untuk memisahkan atau menyaring senyawa aktif yang ada dalam bahan. Hal ini sesuai dengan prinsip ekstraksi pelarut yaitu dengan memisahkan dua komponen atau lebih berdasarkan perbedaan kelarutan komponen tersebut (Suryanto, 2012). Ekstraksi yang dilakukan adalah dengan metode maserasi, proses maserasi ini dilakukan dengan cara perendaman miselium dan broth jamur dengan menggunkan pelarut aseton. Penggunaan pelarut aseton ini dikarenakan aseton merupakan pelarut polar dan mudah menguap. Aseton yang bersifat polar akan menarik senyawa yang bersifat polar sampai non polar (Sarastani et al., 2002). Setalah dimaserasi selama 6 jam, disaring untuk memisahkan miselium dan filtrat. Filtrat yang didapat kemudian diuapkan menggunakan rotary evaporator. Penggunaan alat ini bertujuan untuk menguapkan pelarut dan memperoleh senyawa hasil ektraksi yang diinginkan. Hasil dari proses ini adalah ekstrak kental yang berminyak yang kemudian ditambahkan pelarut etil asetat untuk difraksinasi. Tujuan dilakukan fraksinasi yaitu untuk memisahkan senyawa berdasarkan perbedaan keloparan. Fraksinasi dilakukan sebanyak tiga kali agar semuanya senyawa yang terkandung dalam sampel dapat diambil dengan sempurna. Pelarut etil asetat digunakan untuk menarik senyawa yang bersifat semi polar, seperti fenol, flavonoid, terpenoid, dan steroid yang memiliki sifat antibakteri tertinggi (Pambayun et al., 2007; Reskika, 2011). Dalam penelitian ini, fraksinasi dilakukan dengan metode FCC (Fraksinasi Cair-Cair). Hal ini bertujuan untuk memisahkan dan memurnikan kandungan tertentu yang terdapat dalam sampel berdasarkan perbedaan kepolaran (Departemen Kesehatan Republik Indonesia, 2000). Dalam fraksinasi caircair terjadi perpindahan solut dari satu fasa ke fasa yang lain. Pada fraksinasi cair-cair, fasa yang digunakan adalah dua cairan yang tidak saling bercampur, biasanya digunakan air dan pelarut organik (Harborne, 1987).

Fraksinasi dilakukan menggunakan corong pisah dengan cara ekstrak cair dimasukkan ke dalam corong pisah dan dicampur dengan pelarut etil asetat, setelah itu dikocok. Setelah dikocok, didiamkan beberapa menit sehingga terbentuk dua 
fraksi secara terpisah. Fraksi etil asetat berada di lapisan atas dan fraksi $\mathrm{H} 2 \mathrm{O}$ (air)

berada di lapisan bawah. hal ini disebabkan karena massa jenis air lebih tinggi dari pada massa jenis etil asetat. Selanjutnya, fraksi yang sudah terpisah ditampung dalam wadah yang berbeda diuapkan dan diperoleh ekstrak kasar 0,13 gram untuk pengujian aktivitas antimikroba.

\section{Uji Aktivitas Antimikroba}

Uji aktivitas antimikroba dilakukan dengan metode difusi agar. Metode difusi agar dipilih karena memiliki kelebihan yaitu jumlah zat yang digunakan dapat diatur, cepat, mudah dan sederhana (Valgas et al., 2007). Mikroba uji yang digunakan adalah Staphylococus aureus ATCC 25923 mewakili bakteri Gram positif, E. coli ATCC 25922 mewakili bakteri Gram negatif, dan Candida albicans ATCC 1231 mewakili golongan jamur. Ketiga mikroba uji ini ada dalam tubuh manusia. S. aureus umumnya ditemukan pada kulit, E. coli umumnya ditemukan di usus, dan $C$. albicans ditemukan di mulut dan area kelamin. Pengujian antimikroba ini bertujuan untuk mengetahui apakah terdapat aktivitas antimikroba dari jamur laut yang berasosiasi dengan spons Phyllospongia lamellose.

Dalam pengujian ini, hasil yang diperoleh yaitu terbentuknya zona hambat disekeliling cakram yang ditandai dengan adanya area bening. Hal ini menunjukkan bahwa adanya kepekaan mikroba terhadap ekstrak jamur yang diisolasi dari spons Phyllospongia lamellose. Dalam pengujian ini digunakan kontrol positif dan negatif. Penggunaan kontrol positif berfungsi sebagai kontrol dari zat uji, dengan membandingkan diameter daerah hambat yang terbentuk (Dwijendra, 2014). Sedangkan tujuan penggunaan kontrol negatif agar dapat mengetahui ada tidaknya pengaruh pelarut terhadap pertumbuhan mikroba uji, sehingga dapat dipastikan

Hasil yang didapatkan dari bahwa aktivitas yang ditunjukkan oleh ekstrak ialah senyawa yang terkandung dalam sampel bukan berasal dari pelarut yang digunakan. Dalam penelitian ini, pelarut metanol digunakan sebagai kontrol negatif.

Tabel 1. Hasil pengukuran rata-rata diameter zona hambat antimikroba ekstrak jamur yang berasosiasi dengan alga Halimeda opuntia terhadap bakteri S. aureus ATCC 25923, E. coli ATCC 25922 dan jamur C. albicans ATCC 1231.

\begin{tabular}{cccc}
\hline & \multicolumn{3}{c}{$\begin{array}{c}\text { Rata }- \text { Rata } \\
\text { Diameter Total (mm) }\end{array}$} \\
\cline { 2 - 4 } $\begin{array}{c}\text { Perla } \\
\text { kuan }\end{array}$ & $\begin{array}{l}\text { Staphyl } \\
\text { o cocus } \\
\text { aureus }\end{array}$ & $\begin{array}{l}\text { Escheri } \\
\text { chia } \\
\text { coli }\end{array}$ & $\begin{array}{l}\text { Cand } \\
\text { ida } \\
\text { albic } \\
\text { ans }\end{array}$ \\
\hline $\begin{array}{c}\text { Ekstra } \\
\text { k Etil } \\
\text { Asetat }\end{array}$ & 8 & 6 & 7 \\
$\begin{array}{c}\text { Kontrol } \\
\text { Positif }\end{array}$ & 26 & 19 & 16 \\
$\begin{array}{c}\text { Kontrol } \\
\text { Negatif }\end{array}$ & 0 & 0 & 0 \\
\hline
\end{tabular}

penelitian ini, yaitu adanya zona bening yang terbentuk disekitaran kertas cakram. Pengukuran zona hambat dilakukan dengan cara mengukur jarak dari tepi kertas cakram ke batas lingkaran zona hambat menggunakan jangka sorong (ketelitian $0,01 \mathrm{~mm}$ ) pada beberapa sisi kertas cakram, lalu dirata-ratakan. Berdasarkan kriteria Davis and Stout (1971) kategori lemah kurang dari $5 \mathrm{~mm}$, kategori sedang $5 \mathrm{~mm}$ $10 \mathrm{~mm}$, kategori kuat $10 \mathrm{~mm}-20 \mathrm{~mm}$, kategori sangat kuat lebih dari $20 \mathrm{~mm}$. Dari pengukuran rata-rata diameter zona hambatnya (Tabel 1.), maka daya antimikroba dari sampel spons Phyllospongia lamellose pada bakteri $S$. 
aureus ATCC 25923 sebesar $8 \mathrm{~mm}$ termasuk dalam kategori sedang, untuk bakteri E. coli ATCC 25922 sebesar 6 mm termasuk dalam kategori sedang, dan untuk jamur C. albicans ATCC 1231 sebesar 7 $\mathrm{mm}$ termasuk dalam kategori sedang. Pengamatan pada zona hambat dilakukan 24 jam masa inkubasi bakteri uji dan 48 jam masa inkubasi jamur. Selanjutnya peneliti melakukan pencarian mengenai penelitian yang serupa untuk membandingkan dengan penelitian ini, berdasarkan hasil penelitian dari Payangan (2018) dan Ngantung (2016) sampel Phyllospongia lamellose memiliki aktivitas antimikroba yang berbeda-beda tergantung dari lokasi pengambilan sampel tersebut dan hal ini juga dipengaruhi oleh letak posisi yang berbeda,suhu, $\mathrm{pH}$,dan komposisi mineral.Spesimen yang berada dilingkungan terbuka dan berombak besar cenderung pendek pertumbuhannya atau juga merambat, sebaliknya specimen dari jenis yang sama pada lingkungan yang terlindung dari perairan yang lebih dalam dan berarus tenang, pertumbuhannya cenderung tegak dan tinggi (de Voogd,2005) sehingga hal ini juga yang dapat mempengaruhi sehingga hasil yang di dapat berbeda-beda.

Kekuatan senyawa bioaktif yang terkandung dalam ekstrak spons laut dapat dilihat dengan menggunakan lebar diameter zona hambat sebagai parameternya. Semakin lebar diameter zona hambat yang terbentuk menandakan semakin kuatnya senyawa bioaktif tersebut menghambat pertumbuhan bakteri. Kontrol positifnya digunakan antibiotik kloramfenikol. Kloramfenikol digunakan untuk melawan infeksi yang disebabkan oleh beberapa jenis bakteri Gram positif dan bakteri Gram negatif. Kloramfenikol mempunyai khasiat bakterisid (Sumardjo, 2009). Penggunaan kontrol positif berfungsi sebagai kontrol dari zat uji, dengan membandingkan diameter hambat yang terbentuk. Dari hasil menunjukan diameter zona hambat dari kontrol positif pada bakteri $S$. aureus ATCC $259223 \mathrm{~mm}$ termasuk dalam sangat kuat, E. coli ATCC 2592213 mmtermasuk dalam kategori kuat, dan untuk jamur $C$. albicans ATCC $123116 \mathrm{~mm}$ termasuk dalam kategori sangat kuat. Kontrol negatif yang digunakan yaitu metanol, menunjukkan tidak adanya zona hambat pada pengujian terhadap bakteri $S$. aureus ATCC 2592, E. coli ATCC 25922, dan jamur $C$. albicans ATCC 1231. Hal ini mengindikasikan bahwa kontrol yang digunakan tidak berpengaruh pada uji antimikroba, sehingga daya hambat yang terbentuk tidak dipengaruhi oleh pelarut melainkan karena aktivitas senyawa yang ada pada spons Phylospongia lamellose. Penggunaan metanol sebagai kontrol negatif diperkuat dengan penelitian oleh Ginting (2010), yang menyatakan bahwa kontrol metanol pada uji antibakteri tidak menunjukan adanya aktivitas sehingga dapat dipastikan bahwa metanol tidak berpengaruh terhadap aktivitas yang terbentuk.

\section{KESIMPULAN}

Berdasarkan hasil penelitian yang telah dilakukan dapat disimpulkan bahwa, jamur laut yang berasosiasi dengan spons Phylospongia lamellose yang diperoleh dari Desa Tumbak, Kecamatan Pusomaen, Kabupaten Minahasa Tenggara memiliki aktivitas antimikroba terhadap bakteri Staphylococus aureus, Escherichia coli, dan jamur Candida albicans.

\section{SARAN}

Perlu dilakukan penelitian untuk mengetahui kandungan antioksidan sampel Phylospongia lamellose.

\section{DAFTAR PUSTAKA}

Coley, P. D., Kursat, T. A. 2000. Are Tropycal Fungal Endophytes Hyperdiverse. Ecology Latters. 3(3):267- 274.

Bara, R. 2007. Study metabolic rate and metabolism in the spons Haliclona oculata using different $13 \mathrm{C}$ labeled substrates. Thesis. Wageningen University. The Netherlands. 
Bugni, T. S., Ireland, C. M. 2004. Marinederived fungi: A Chemically.

Davis, W. W., Stout, T. R. 1971. Disc Plate Method of Microbiological Assay. Journal of Microbiology. 22:659665.

Departemen Kesehatan Republik Indonesia, 2000. Parameter Standard Umum Ekstrak Tanamn Obat. Direktorat Jenderal Pengawasan Obat dan Makanan, Jakarta.

De Voogd NJ.2005. Indonesian Sponges: Biodiversity and Mariculture Potential.Netherlands: University of Amsterdam

Dwijendra, I. M. 2014. Aktivitas Antibakteri dan Karakterisasi Senyawa Fraksi Spons Lamellodysidea herbacea yang Diperoleh dari Teluk Manado [skripsi]. Program Studi Farmasi FMIPA Universitas Sam Ratulangi, Manado.

Ginting, E. L., Warouw, V., Suleman, R. W. 2010. Aktivitas Antibakteri Dari Ekstrak Kasar Bakteri Yang Berasosiasi Dengan Sponge Acanthostrongylophora sp. [skripsi]. Fakultas Perikanan dan Ilmu Kelautan Universitas Sam Ratulangi, Manado.

Harborne, J. B. 1987. Metode Fitokimia. Edisi ke-2. ITB. Bandung.

Kohlmeyer J, Kohlmeyer E . 1979. Marine mycology: The Higher Fungi. Academic Press, New York.

Lee, Y.K., Lee, J.H., Lee, H.K. 2001. Microbial symbiosis in Marine
Sponss. Pdf.

Ngantung, A.,Sumilat, D., Bara, R. Uji aktivitas antibakteri dari spons dictyonella funicularis dan phyllospongia lamellosa yang diambil pada perairan bunaken. Jurnal Pesisir dan Laut. 2 (1).

Nikham dan Taty E.B. 2012. Uji Baku Antibakteri dari Buah Mahkota Dewa (Phaleria Macrocarpa (SCHEFF) Boerl.) Hasil Iradasi Gamma dan Antibiotik Terhadap Bakteri Patogen. Prosiding Pertemuan Ilmiah Ilmu Pengetahuan dan Teknologi Bahan. Serpong,pp. 168-174.

Payangan, G., Fatimawali, Rotinsulu, H. Uji aktivitas antimikroba jamur laut yang berasosiasi dengan spons phyllospongia lamellose. Phamacon Jurnal Ilmiah Farmasi UNSRAT. 7 (3).

Reddy, D.R.S., Audipudi, A.V., Reddy, G.D., and Bhaskar, C.V.S. 2011. Antioxidant,

AntiInflammator $\mathrm{y}$ and Antifungal Activity of Marine Sponge

Subergargoria suberosaDerived Natural Products. Interna-tional Journal of Pharm Tech Research.Vol.3,No.1, pp. 342348.

Sarastani D, Soekarto ST, Muhchtadi TR, Fardiaz D, Apriyantono A. 2002. Aktivitas antioksidan ekstrak dan fraksi ekstrak biji antung (Parinarium glaberrimum). Jurnal Teknologi dan Industri Pangan. 13(2). 
PHARMACONJurnal Ilmiah Farmasi - UNSRAT Vol. 8 No. 4 NOVEMBER 2019 ISSN 2302 - 2493

Sastroasmoro, S. 2005. Using Cyprofloxantin in Indonesia. Indonesia HTA. 1-28 hlm.

Sumardjo,Damin. 2009. Pengantar Kimia. Buku Kedokteran EGC. Jakarta.

Suryanto, E. 2012. Fitokimia Antioksidan. Penerbit Putra Media Nusantara. Surabaya.

Valgas, C., Souza, S.M.D., Smania, E.F.A, and Artu, S. 2007. Screening methods to determine antibacterial activity of natural products. Brazilian Journal of Microbiology, 38, p. 369-38. 